\title{
CENTERING THE MARGINS: KNOWLEDGE PRODUCTION IN THE INTRODUCTORY ARCHAEOLOGY COURSE
}

Kylie E. Quave, Shannon M. Fie, AmySue Qing Qing Greiff, and Drew Alis Agnew

THIS IS A POST-REVIEW PREPRINT OF AN ARTICLE PUBLISHED IN Advances in Archaeological Practice. PLEASE CONSULT AND CITE THE VERSION OF RECORD AT http://www.cambridge.org/core/journals/advances-in-archaeologicalpractice/article/centering-the-margins/20B3DF276E6B1DB83CF63758402E29CA (DOI: 10.1017/aap.2020.43). The version of record also includes supplementary materials.

Kylie E. Quave University Writing Program and Department of Anthropology, The George Washington University, 2100 Foxhall Rd NW, Washington, DC 20007, USA (kquave@gwu.edu)

Shannon M. Fie Department of Anthropology, Beloit College, 700 College St., Beloit, WI 53511, USA (fies@ beloit.edu, corresponding author)

AmySue Qing Qing Greiff Independent Scholar, Madison, WI, 53703, USA

Drew Alis Agnew Independent Scholar, Madison, WI, 53703, USA 
Abstract: Teaching introductory archaeology courses in US higher education typically falls short in two important ways: the courses do not represent the full picture of who contributes to reconstructing the past and do not portray the contemporary and future relevance of the archaeological past. In this paper, we use anti-colonial and decolonial theories to explain the urgency of revising the introductory archaeology curriculum for promoting equity in the discipline and beyond. We detail the pedagogical theories we employed in revising an introductory archaeology course at a small liberal arts college in the US and the specific changes we made to course structure, content, and teaching strategies. To examine the impacts on enrolled students and on who chose to enroll in the revised archaeology curriculum, we analyze student reflection essays and enrollment demographics. We find that students developed more complex understandings of the benefits and harms of archaeological knowledge production and could articulate how to address archaeology's inequities. We also found that enrollment in archaeology courses at the college shifted to include greater proportions of students of color. These results support the notion that introductory archaeology courses should be substantially and continually revised.

Resumen: Típicamente la docencia de los cursos arqueológicos de universidades de los Estados Unidos se queda corta de dos maneras: no presentan la imagen completa de quiénes contribuyen a la reconstrucción del pasado y no retratan la relevancia actual y futura del pasado. Aquí usamos teorías anti-coloniales y descolonizadas para explicar la urgencia con que hay que modificar el currículo arqueológico para promover equidad social en la disciplina y más allá de la disciplina. Detallamos las teorías pedagógicas que utilizamos en la revisión de nuestro curso en una universidad de artes liberales en EEUU. Especificamos los cambios que hicimos con la estructura del curso, el contenido y estrategias de instrucción. Para examinar el impacto a los alumnos y averiguar quiénes tomaban interés en el curso, analizamos ensayos reflexivos y cambios demográficos de inscripción. Vemos que los alumnos desarrollaron conocimientos más complejos sobre los beneficios y daños de la producción del conocimiento arqueológico y que podrían indicar como abordar las desigualdades de la arqueología. También encontramos que las inscripciones en los cursos de arqueología de la universidad cambiaron para incluir proporciones mayores de estudiantes de color. Estos resultados soportan la idea que los cursos de arqueología deberían ser revisados substancialmente y continuamente. 
Post-secondary archaeology and prehistory introductory courses typically do not center the potential of archaeology to improve human interests in the present and future. At predominantly white institutions (PWIs; Brown and Dancy 2010) in the United States (US), these courses are usually organized and presented to students in ways that perpetuate discrimination and social marginalization. This could be mitigated by "centering the margins," in which we mean to center the needs and interests of marginalized peoples and archaeological stakeholders. Furthermore, we center marginalized theoretical paradigms that are taught as "alternative" rather than as valid and effective. We reveal the limitations and possibilities of archaeological knowledge production, encouraging students (and ourselves as educators and researchers) to ask, "who benefits from archaeology, who is harmed, and how might we imagine a different way of studying and engaging with the past?"

Our work to revise our course at a predominantly-white small liberal arts college (SLAC) in the US examined how archaeology can contribute to a more equitable society, which Ann Stahl recently described as an "effective archaeology" (2020), while integrating inclusive and justice-oriented pedagogical methods. This work follows calls to re-imagine how we teach postsecondary archaeology (Hamilakis 2004; Hutchings and La Salle 2014), but is not unique to archaeological pedagogy (FitzPatrick Sifford and Cohen-Aponte 2019; Harbin et al. 2019; Shelton 2020). Our approach builds on the possibilities Maria Franklin outlined fifteen years ago for historical archaeological research: "writing inclusive pasts, challenging traditional, dominant views of history, and wiping out divisive myths and stereotypes" (Franklin 2005:194).

In this paper we 1) explain the limitations of introductory archaeology and prehistory courses, 2) demonstrate how we addressed these limitations by redesigning an introductory course at a US PWI SLAC, and 3) examine the re-design's impacts on students. In Fall 2017 the authors taught a revised version of our introductory course, ${ }^{1}$ formerly titled "Archaeology and Prehistory," which Fie has taught in the new format four times. To demonstrate the impacts of these changes on our campus, we present results from an IRB-approved study of student reflections, and enrollment trends over time by race and ethnicity.

Archaeology and prehistory courses typically focus on describing archaeological method and theory, major trends over time, and depicting the human past chronologically or in order of sociopolitical complexity. To some, this may seem a neutral approach to representing the field and its study of the human past. However, this approach fails to capture the diversity of epistemologies used in the field and may lead students to understand the past as a single story; it also risks reifying the myth of human societies as a teleological march from "savagery" toward "civilization". Furthermore, survey courses are typically oriented around testing students' capacities to memorize facts such as dates and culture names, even while such assessment methods may not be the most inclusive (Montenegro and Jankowski 2017) or the most effective for capturing archaeology's social relevance.

Hutchings and La Salle (2014) recently called for an anti-colonial approach to teaching archaeology, arguing that the colonialist version of teaching archaeology must be rectified. Following Tuck and Yang (2012), Dei and Asgharzadeh (2001), and Mahuika (2008), Hutchings 
and La Salle term their approach "anti-colonial" rather than "decolonial" to go beyond the mere recognition of colonized ways of knowing to take an "explicitly political stance of resistance to all forms of colonialism" (Hutchings and La Salle 2014:40). The anti-colonial approach is also methodologically and theoretically heterogeneous, but particularly centers anti-racist, antioppressive, Indigenous, feminist, queer, and other critical and activist paradigms. The changes made by Hutchings and La Salle (2014:30) were for courses of 75 to 350 students, while the classes we taught have a 30-student enrollment maximum; this enrollment difference allowed us to incorporate different kinds of assignments and ways of learning (particularly using principles of universal design for learning [UDL]), which we detail below.

Maxine Oland (2020) recently published an urgently-needed guide on teaching archaeology through inclusive pedagogy. The changes we propose are similar in calling for greater attention to the pluralistic needs of students and in designing courses that incorporate UDL principles. In the UDL framework, instructors change the environment (rather than the learner) in order to support students' growth as "expert learners" and to help them be "purposeful and motivated, resourceful and knowledgeable, and strategic and goal driven" (CAST 2018a). Oland includes actionable suggestions for creating a safe and welcoming environment, offering students more agency, and generating meaningful, active learning experiences. In this study, we advocate for deeper structural changes that are particular to the epistemological problems of archaeology, including re-assessing learning goals, text choices, case studies, and how we present the potential future of the discipline to students. We further offer evidence for the effects of these changes.

\section{Why Reimagine the Introductory Archaeology Course?}

The purpose of teaching archaeology is not simply to convey the contours of the past, but also to benefit people in the present and future (e.g., McGuire 2008; Merriman 2004; Richardson and Almansa-Sánchez 2015; Supernant et al. 2020). The study of the past is not neutral: some individuals, communities, and populations benefit from learning about archaeology (e.g., BattleBaptiste 2007; Franklin and Lee 2020; Franklin and Paynter 2010; Lane 2015; Logan 2016; Sandweiss and Kelley 2012; Southwell-Wright 2013; Stump 2019; Thiaw 2011), while others are harmed (e.g., Arnold 1990; Atalay 2006; Deloria 1997; Watkins 2010). Archaeological representations of the past, whether in an undergraduate course or elsewhere, masquerade as objectively truthful accounts; however, our understanding of the archaeological record is biased toward those places where research has been conducted, what kinds of questions have been asked, and whose experience and worldview are given primacy. Scientific epistemologies-including archaeological ways of knowing--are often considered natural or neutral, yet a long tradition of feminist critique demonstrates that is not the case (Haraway 1988; TallBear 2014). Educators may value the use of archaeology to address social conditions in the present, but 
typical ways of teaching archaeology have limited capacity to explain contemporary inequities due to biases in how we know what we (think we) know and how we present it to others.

Enrollment of students of color and students from lower socioeconomic backgrounds is low in archaeology courses (Hamilakis 2004:295). This trend continues into the professional ranks and every aspect of knowledge production in the discipline (Heath-Stout 2019, 2020; Heath-Stout and Hannigan 2020; White and Draycott 2020), especially in the underrepresentation of Black archaeologists (Franklin 1997; Odewale et al. 2018). One factor affecting racialized and socioeconomic disparities may be whether students see their identities and their interests represented in both the stories archaeologists tell about the past and who gets to tell those stories (i.e., whose scholarship they read).

The Society of Black Archaeologists, for example, was established 2011; part of its mission is to promote the work of Black archaeologists (SBA n.d.). In June 2020, over 2600 people registered for the SBA panel discussion "Archaeology in the Time of Black Lives Matter" (SBA 2020). While there is newly urgent (yet overdue) interest in these themes within the discipline, archaeologists have long called for multi-vocality and a greater diversity of perspectives (Agbe-Davies 2002; Atalay 2008; Bardolph 2014; Gnecco 1999; Perry 2019) and have found the discipline wanting (Conkey 2007; Fulkerson and Tushingham 2019; Morgan 2019). The voices and perspectives of a few have been made dominant partly through what instructors and textbook authors tend to present as normative archaeological theory. Moreover, Indigenous knowledge and archaeological theories informed by Black Marxist and Black feminist thought are briefly mentioned or ignored within classroom readings and discussions.

In a study of multi-edition archaeology textbooks, Lyman found that theories presented in textbooks "reflect the state of the art in a discipline at the time of [...] publication" but that "these volumes [...] do not provide nuanced and thorough reflections of disciplinary history" (2010:1). Yet rather than merely lacking in nuance, textbooks present the state of the discipline according to those already afforded the most prominent platforms in the field; these platforms disproportionately elevate white, middle-class men from elite universities (Conkey 2007; Fulkerson and Tushingham 2019). As Conkey points out in a survey of archaeological theory readers, "big scale processes" such as settlement patterns and technology are given prominence (Conkey 2007:291; see also Cobb 2014) and "Anglo-American archaeology is still nearly a completely white and middle-class enterprise" (2007:304). Both in theory manuals and in textbooks, feminist and critical theories are treated as marginal and excluded from mainstream accounts of dominant theoretical paradigms. They may be cast as unscientific and lacking in objectivity, while archaeologists writing textbooks consider more processually-aligned theories essential. Hutchings and La Salle (2014:30) describe this phenomenon in newer textbooks as well; for example, the fourth edition of Michael Chazan's (2017) World Prehistory and Archaeology: Pathways Through Time lists post-processual archaeology as "Alternative Perspectives" and details gender, agency, and Indigenous perspectives in a section titled "Branching Out" (Supplemental Table 1). In some textbooks, theories not aligned with processualism are presented in sidebars rather than paragraphed prose, if mentioned at all. 
Some theories are indeed cited more often than others, and textbooks are simplified versions of approaches to the past. However, the presentation of certain theories as dominant and essential perpetuates the marginalization of particular ways of knowing. Archaeologists have the responsibility to engage multiple perspectives on the past to forge better futures for more humans. As Colleen Morgan remarks, in reference to the limited representation of racial and gender identities in archaeology courses at the University of York, "the canon is archaeology's own creation story, repeated and handed down through successive generations of scholars. [...] The first year of undergraduate education is a critical time to form the archaeological canon that students will take forward and replicate, or repudiate in time" (Morgan 2019:10). We must challenge normative archaeology by unsilencing marginalized narratives.

The organization of textbook units and chapters warrant further critical consideration (Supplemental Table 1, Supplemental Table 2). Archaeology courses and their attendant textbooks are typically organized in a contrived order of seemingly "primitive" to "civilized", whether by region or sociopolitical complexity: they progress from hominins to bands, tribes, chiefdoms, states, and empires (Hutchings and La Salle 2014:30). Whether intended or not, these seemingly naturalized renditions of progress narratives reify myths about inevitable marches toward civilization, and they promote an imagined social distance between egalitarian and nonagricultural societies and the agricultural empires taught at the end of the semester. Some societies are treated as exceptional in textbooks: where states and empires did not develop, where states developed within regions dominated by nonstate societies, and where sociopolitical complexity developed without agriculture. The result is a narrative arc that reinforces stereotypes and marginalizes the rest.

\section{Addressing Limitations through Course Revision}

Revising our introductory archaeology course was informed by larger pedagogical theories as well as critiques particular to archaeological ways of knowing. First, we subscribe to a model of learning-focused course design (also known as backward-integrated design): crafting courses based on what one expects students to be able to do by the end of a course rather than being governed by content goals (Grunert O'Brien et al. 2008). We thus moved away from a content-focused, traditional syllabus of geographic and/or neo-evolutionary themes from "primitive forward". Instead, we planned the course around values and skills we want students to hold at the end of the semester and even years later. In this case, we introduced them to archaeological theory and methods and the human past, but also prepared them to critically analyze evidence about humans and to apply lessons from the past. We built analytical capacities that students could take with them beyond the classroom and beyond archaeology.

We also subscribe to the tenets of critical pedagogy and democratic, multi-directional learning espoused by bell hooks (1994) and Paulo Freire (1985), which involve de-centering the instructor as an all-knowing orator; we reject the idea that students are empty vessels to be filled 
with unquestionably neutral knowledge. We are also influenced by the pedagogy of kindness, which emphasizes compassion and understanding of students' needs rather than positioning students as antagonists to instructors (Denial 2019). To integrate these pedagogies, and to respond to the call to action by Hutchings and La Salle (2014), we shifted which voices were given prominence, the course's narrative arc, how the past was linked to a better human future, and how students could demonstrate/develop their place in archaeological knowledge production.

\section{The Course Prior to Revision}

At our US PWI SLAC, the introductory archaeology course was originally designed around archaeological method and theory coupled with "prehistory". As an introductory survey course, we enroll around 30 students per section. Enrollees include intended and declared anthropology majors and students fulfilling general education requirements who are not particularly interested in anthropology. While we sometimes have an undergraduate teaching assistant, there are no breakout sections for labs or discussion.

Prior to Fall 2017, we taught slide-based lectures and assigned a common prehistory textbook. Sometimes we also assigned Kenneth Feder's (2017) Frauds, Myths, and Mysteries, which students used to develop group presentations on epistemology and public knowledge production. The course began with an introduction to archaeological methods, including the formulation of research questions, field strategies, excavation methods, and laboratory analyses. The majority of the semester covered the "prehistory" archaeologists study. Most class periods consisted of presentations on how different approaches and methods are used to understand the major cultural developments in geographic regions, from early tool user hominids in Africa through complex state developments in Eurasia and the Americas. Though discussion was limited, we often took students into the Logan Museum of Anthropology to engage with course theme-related objects and exhibits. Assessment of student learning was primarily short-answer tests.

\section{The Revision Process}

While the course textbook, lectures, and lesson plans were regularly updated, we recognized the need for major revision. Students were primarily drawn to the course to learn about pyramids and Vikings, while some cultural anthropology-oriented majors merely participated unenthusiastically to meet requirements. Occasionally, Fie explored re-envisioning the course, but the lack of an alternative textbook posed a significant challenge.

In Spring 2017, Fie collaborated with independent study students to re-imagine the course to focus on relevant and applied archaeologies, including themes such as identity, power and privilege, conflict, sustainability, and climate change; to explore them as recurring issues addressed in different ways by societies in different places and times; and to illustrate how archaeologists identify and make sense of how and why societies differ in those ways. Fie, along 
with Agnew and five other students identified new course readings (that were accessible to nonexperts, and others written for archaeologists) and developed supplementary lecture content, discussions, and activities. They identified sources from a plurality of perspectives and curated a list for instructors to choose from as they crafted a syllabus. In Summer 2017, Quave revised the materials and pedagogical approach through the Mellon Foundation-funded "Decolonizing Pedagogies" workshop at Beloit College. Subsequently, all four authors revisited our objectives for the new course and made substantial revisions to the course as outlined in Tables 1 and 2 (Supplemental Text 1). During the Fall 2017 semester, we met weekly to discuss and re-calibrate according to student engagement with the material.

\section{The Revised Course}

The revisions to the course re-centered students' perceptions of authoritative knowledge and included case studies and theoretical and methodological perspectives that better represent what applied archaeologists aspire for the discipline to accomplish. Our approach emphasizes critical assessment of how archaeologists know what they know, whose voices are centered, and how knowledge is constructed and disseminated (Harbin et al. 2019; Kishimoto 2018). These changes are not particular to archaeology, but are worth mentioning because they shaped all pedagogical decisions. In this section, we describe specific pedagogical methods and examples for meeting the goals laid out in the first half of this paper.

How Did We De-center the Instructor? Following the tenets of democratic and participatory/experiential pedagogies (Carlson and Apple 2018; Freeman et al. 2014; Freire 1985), we shifted the focus away from the instructor as unquestioned academic authority. Instead, we developed our course around student engagement and multidirectional learning: students are collaborators in the production of knowledge within the course and must acknowledge how their positionality shapes their understanding of course material (Takacs 2003). Rather than emphasize instructor-to-student information transfer through lectures as we had before, we included short lectures with each unit to introduce a theme and human problem, but students spent the majority of class time in active learning. Furthermore, we encouraged students to take our classroom dialogues beyond the course, often asking them to imagine they were at a family meal explaining difficult course concepts to non-experts. Thus, we emphasized the application of classroom knowledge production beyond class walls.

How Did We Ensure Pluralistic Perspectives on the Past? Students largely trust textbooks as authoritative and assume that the writer is removed from the content of their writing (Olson 1980). Similarly, students are usually detached from the process of course design and assume that instructors require the most canonical readings beyond the textbook. Of course the canon is constructed through citation practices within a discipline rather than being natural or based on some objective intellectual merit. As instructors, we must take responsibility for constructing the perceived canon in the classroom (and for emphasizing that who we read and who we cite are decisions shaped by our worldviews and priorities). Fostering equitable citation practices is urgent (Edmonds 2019; Mott and Cockayne 2017); the "Cite Black Women" 
movement, begun in November 2017, called attention to the need to center the knowledge production of marginalized scholars, specifically Black women. We replaced the large, expensive introductory textbook, brought case studies and theories by underrepresented scholars to the fore, included more "nonacademic" sources written by other types of experts, and positioned Black, Indigenous, and critical ontologies alongside positivist ways of knowing to demonstrate the plurality of theoretical approaches.

We realize that many university programs require instructors to use a survey textbook for introductory courses. For our revised course, we adopted Paul Bahn's (2012) Archaeology: A Very Short Introduction to provide one of many perspectives. Bahn's text does two important jobs:1) at $\$ 12$, it costs one-tenth what a typical introductory archaeology text costs and thus makes the course more accessible, and 2) it precludes the unwelcome role of a single, authoritative source written by one or two archaeologists. We use it to discuss text authority and assumptions about textbooks, jumping off from Lee Lyman's (2010) study. The chapters center on method-driven topics but also address archaeologists' responsibilities to the public and heritage stewardship. The brevity of Bahn's volume (just 100 pages) prompts students to ask, "what is missing?"

We also chose open-source readings in addition to institutionally accessed readings. Including think-pieces and blogs (e.g., Abu Hadal 2013; Black Trowel Collective 2016) alongside academic journal articles and chapters helped students to see the various venues in which archaeological knowledge is disseminated and to think about who benefits from and is harmed by archaeological reconstructions of the past. And starting the semester with different perspectives from scholarly and non-academic texts showed the value of diverse ways of knowing the past while also providing an opportunity to question the supremacy of Eurocentric scientific traditions. In teaching archaeological theory, Black feminist archaeology (BattleBaptiste 2011) was one of the first theoretical paradigms with which students reconstructed the past. In introducing the humanistic and scientific tendencies of archaeologists, we asked students to read case studies on the Pleistocene origins of the first Americans that offer pluralistic views in science (Deloria 1997; Grayson and Meltzer 2003).

How Did We Center Ethical Concerns? In order to center Indigenous and antiracist ontologies, we eliminated the terms "prehistory" and "New World" and drew attention to the trouble with using those terms and others such as "Classic" and "Horizon." The first day of classes, we asked students where they had heard these terms and what they meant to preempt a discussion of the harm done by their uncritical use. Students examined how "New World" and "Old World" privilege the "discovery" narrative of European exploration rather than recognizing deep histories of peoples in the Americas with their own cultural trajectories, and they came to realize that "prehistory" is a disparagingly primitivizing term. Though "prehistory" is often used uncritically, it warrants scrutiny due to the fact that it arbitrarily separates societies interpreted to be "pre-literate" from those with surviving written records (deemed readable by outsiders). The label others, marginalizes, and primitivizes societies that have largely been subjected to colonial 
rule and thus reifies global inequalities. Having this discussion in the first week gave space for students to see how seemingly minor language choices can have major harmful impacts.

In previous versions of the class, we taught ethics most directly in the final unit of the semester (though we taught occasionally with Feder's Frauds, Myths, and Mysteries [2017]; which prompted additional discussions of ethics throughout). However, in the revised course, ethical questions were posed from the start of each unit. Students were iteratively prompted to ask and answer "Who is helped and who is harmed by the reconstruction of the archaeological past?" Class discussions and assignments focused on how producing and consuming archaeological knowledge requires ethical approaches. For example, when teaching the scientific method we watched an episode of Ancient Aliens in order to examine how an illusion of objectivity was constructed to perpetuate racist myths (Bond 2018). Throughout the semester, we asked students to consider how they reify marginalizing narratives about the past through their consumption choices and to consider how to mitigate or avoid the impacts of those decisions.

How Did We Overcome Progress Myths? Teaching the past chronologically and/or following a neo-evolutionary progression of pre-humans to empires positions Euro-American and White perspectives as neutral ways of knowing and reproduces the harmful assumptions of a lockstep march toward civilization. In this way, any societies not "progressing" are implicitly represented as backward. To avoid such teleological ways of knowing, we organized the course conceptually along themes of social relevance. Instead of organizing by geographic boundaries, chronological units, or evolutionary progress, we chose problems to investigate and case studies to illustrate them (Table 1, Table 2). Importantly, we explained to students why we avoided the neo-evolutionary organization for the course. We did not erase regional sociopolitical trajectories, but we did not present a single trajectory as normative. The themes were wideranging and timely: for example, a unit on migration, climate change, sustainability, and health included case studies such as Irish immigrant acculturation and respectability politics, biocultural reconstructions of dairy consumption in Neolithic Central Europe, Neandertals and disability, Maya responses to climate change, Inka pastoralism, archaeologies of fire management, historical food insecurity in Ghana, and the Norse collapse in Greenland.

Table 1. Learning Objectives of the Course before and after Revision.

\begin{tabular}{|c|c|}
\hline Before & After \\
\hline Students will: & $\begin{array}{l}\text { Engaging with both academic and public science } \\
\text { resources, as well as completing applied } \\
\text { archaeology assignments will allow students to: }\end{array}$ \\
\hline $\begin{array}{l}\text { comprehend the main events, actors, and evidence } \\
\text { involved in human history }\end{array}$ & $\begin{array}{l}\text { compare diverse global cases and patterns of early } \\
\text { and "prehistoric" human activities }\end{array}$ \\
\hline $\begin{array}{l}\text { summarize changes over time and basic methods } \\
\text { and theories, including biases in interpreting the past }\end{array}$ & $\begin{array}{l}\text { critique archaeological epistemologies, including } \\
\text { methods and theories, and their historical origins in } \\
\text { colonialism }\end{array}$ \\
\hline
\end{tabular}


demonstrate an understanding of the historical, cultural, social, and political conditions of identity formation and function in human society, including the ways in which these conditions influence individual or group status, treatment, or accomplishments appreciate the multiple voices represented in reconstructing the past while developing an understanding of the critical thinking required to assess claims about the human past apply anti-colonial archaeology to link lessons from the past to solutions for the most urgent issues facing societies today

Table 2. General Syllabus Schedule before and after Course Revision.

\begin{tabular}{|c|c|c|c|}
\hline \multicolumn{2}{|c|}{ Example of a "before" syllabus } & \multicolumn{2}{|c|}{ Example of an "after" syllabus } \\
\hline Unit & Weekly themes & Unit & Weekly themes \\
\hline \multirow{2}{*}{$\begin{array}{l}\text { Archaeological } \\
\quad \text { and } \\
\text { Paleoanthropol } \\
\text { ogical Methods } \\
\text { and Theories }\end{array}$} & $\begin{array}{l}\text { Science and archaeology; public } \\
\text { perceptions of archaeology }\end{array}$ & \multirow{2}{*}{$\begin{array}{l}\text { What \& how } \\
\text { do } \\
\text { archaeologists } \\
\text { observe? }\end{array}$} & Colonial origins of archaeology \\
\hline & $\begin{array}{l}\text { Origins of paleoanthropology and } \\
\text { archaeology in 19th century }\end{array}$ & & $\begin{array}{l}\text { Archaeology's big questions; } \\
\text { methods; garbology }\end{array}$ \\
\hline \multirow{3}{*}{$\begin{array}{l}\text { Human } \\
\text { Evolution and } \\
\text { Migration }\end{array}$} & $\begin{array}{l}\text { Evolution and education debates; } \\
\text { early hominins }\end{array}$ & \multirow{2}{*}{$\begin{array}{l}\text { How do } \\
\text { archaeologists } \\
\text { explain what } \\
\text { they observe? }\end{array}$} & $\begin{array}{l}\text { Simulated excavation; } \\
\text { hypotheses and theories; } \\
\text { positivism and scientism; Black } \\
\text { feminist archaeology }\end{array}$ \\
\hline & $\begin{array}{l}\text { Pleistocene adaptations; archaeology } \\
\text { hoaxes and scientific method }\end{array}$ & & $\begin{array}{l}\text { Indigenous archaeology; } \\
\text { epistemology and the past as } \\
\text { political (monuments); } \\
\text { pseudoscience }\end{array}$ \\
\hline & $\begin{array}{l}\text { Anatomically and behaviorally } \\
\text { modern humans; hunter-gatherers in } \\
\text { Holocene }\end{array}$ & \multirow{3}{*}{$\begin{array}{l}\text { How we } \\
\text { represent the } \\
\text { past matters }\end{array}$} & $\begin{array}{l}\text { Stakeholders, representation, and } \\
\text { self-determination }\end{array}$ \\
\hline \multirow{4}{*}{$\begin{array}{l}\text { Emerging } \\
\text { Complexity }\end{array}$} & $\begin{array}{l}\text { Mesolithic and Archaic changes in } \\
\text { human behavior }\end{array}$ & & $\begin{array}{l}\text { Nationalism and extremism co- } \\
\text { opting the past }\end{array}$ \\
\hline & $\begin{array}{l}\text { Hunter-gatherer lifeways; Paleodiet } \\
\text { myths }\end{array}$ & & $\begin{array}{l}\text { Ethics and "looting"; } \\
\text { "Discovery" narratives }\end{array}$ \\
\hline & $\begin{array}{l}\text { Agriculture, sedentism, and } \\
\text { emergence of inequality; } \\
\text { Moundbuilder myths }\end{array}$ & \multirow{3}{*}{$\begin{array}{c}\text { Archaeologies } \\
\text { of inequality, } \\
\text { power, \& } \\
\text { privilege }\end{array}$} & $\begin{array}{l}\text { Anarchist archaeology, } \\
\text { primitivism }\end{array}$ \\
\hline & North American chiefdoms & & $\begin{array}{l}\text { Eurocentricity; archaeology of } \\
\text { enslavement }\end{array}$ \\
\hline $\begin{array}{l}\text { Old World } \\
\text { Complex } \\
\text { Societies }\end{array}$ & $\begin{array}{l}\text { Early states and empires in Asia and } \\
\text { Africa; Egyptian pyramid } \\
\text { construction myths }\end{array}$ & & $\begin{array}{l}\text { Black feminism and human } \\
\text { evolution; gender disparities; } \\
\text { challenging the gender binary }\end{array}$ \\
\hline
\end{tabular}




\begin{tabular}{|c|c|c|c|}
\hline & $\begin{array}{l}\text { State development theories; Bronze } \\
\text { Age/Iron Age/Neolithic Europe; } \\
\text { Atlantis myths }\end{array}$ & & $\begin{array}{l}\text { Food access inequality; limits of } \\
\text { archaeology textbooks }\end{array}$ \\
\hline \multirow{4}{*}{$\begin{array}{l}\text { New World } \\
\text { Complex } \\
\text { Societies }\end{array}$} & Early Mesoamerican complexity & \multirow{3}{*}{$\begin{array}{l}\text { Archaeologies } \\
\text { of migration, } \\
\text { climate } \\
\text { change, } \\
\text { sustainability, } \\
\& \text { health }\end{array}$} & $\begin{array}{l}\text { Migration and assimilation; } \\
\text { respectability politics in } \\
\text { historical archaeology }\end{array}$ \\
\hline & $\begin{array}{l}\text { Mesoamerican chiefs and lords; } \\
\text { mortuary cultures }\end{array}$ & & $\begin{array}{l}\text { Health, disability, and care; food } \\
\text { insecurity and access }\end{array}$ \\
\hline & $\begin{array}{l}\text { Ancient aliens myths; Andean } \\
\text { statecraft; collapse }\end{array}$ & & Climate change denial; collapse \\
\hline & $\begin{array}{l}\text { Ethical concerns; the past for the } \\
\text { future }\end{array}$ & $\begin{array}{l}\text { Portraying } \\
\text { past peoples } \\
\text { for plural } \\
\text { publics }\end{array}$ & $\begin{array}{l}\text { Presentism and popular media; } \\
\text { archaeology for the future }\end{array}$ \\
\hline
\end{tabular}

How Did We Orient the Past toward the Future? Another guiding principle of the course was how both the past and explanations of it are political. We featured case studies on how archaeologists have studied monuments, their destruction, and the value of public memory. We discussed how cross-cultural understandings of monument destruction in the past could be applied to decisions about Confederate monuments' futures and what was at stake for human wellbeing (Carter 2018). We also critically considered "looting" and unauthorized excavations by examining ethnographic studies of artifact destruction and collection in different regions and times (Dunn 2016; Hart and Chilton 2015). Differentiating why some types of non-scientific excavations are considered illegal or immoral gave students an opportunity to examine colonialist attitudes about heritage conservation. Supplemental Text 1 expands on more themes and case studies, with lesson planning notes for instructors.

How Were Assessments of Archaeological Knowledge Made Accessible and Relevant? Using UDL principles and active learning, we created assessments that prioritized garnering the past in service to a better future. Like Oland's (2020) changes to her introductory archaeology course, we designed assignments for diverse learning needs with multiple ways of consuming course materials and of producing course knowledge for assessment of student learning (CAST 2018b). This meant that assignments went beyond writing prose: we incorporated presentations, listening exercises, and multimedia/multimodal projects (e.g., blogging [Figure 1]). Learning was enhanced by technology, was collaborative and cooperative, and was linked to real-world scenarios. Students were provided with rubrics, activity formats were varied, student diversity was respected, and we used frequent, scaffolded assessments (Boothe et al. 2018:Table 1). We offer details on a selection of assessments in our supplementary materials. 


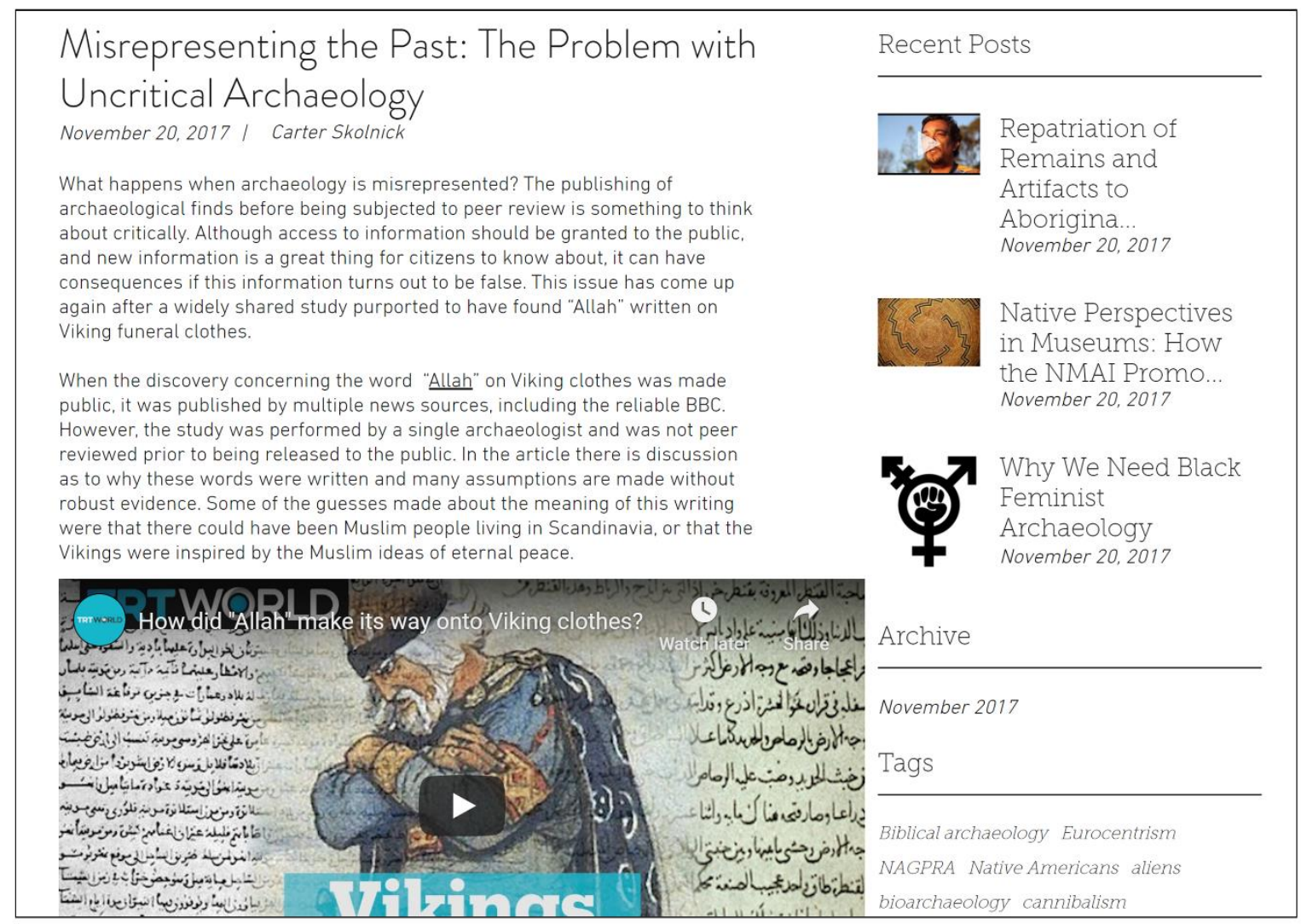

Figure 1. Screenshot from the student-reviewed and student-written course blog site: "Past Forward".

Students critically interrogated archaeological ways of knowing through a simulated excavation. A rejection of the "sandbox approach," this alternative method by Paul Thistle (2012) uses paper units and late 20th-century artifacts, and drawn features, to simulate spatial relationships to be carefully and accurately recorded. Students must collaborate to properly contextualize individual units that are compared across the simulated site. Upon completion of a collaborative site map, students wrote reports in which they were required to generate hypotheses, reflect on how their positionality shapes their epistemology (Takacs 2003), and examine their biases in interpreting the past through the material record (Supplemental Text 2). They also had to discuss to whom this past is relevant and who gets to decide where to do research and how, while considering the findings of the simulated excavation in comparison with excavations at a historic site on campus (Starck and Green 2014).

Assignments were designed to call attention to issues of access to the past. Archaeology's visual emphasis, particularly when teaching in the slide-lecture format, comes at the cost of accessibility for visually impaired students and stakeholders; 3-D printing is proposed as one way to mitigate this problem (Hugo 2017). To supplement our teaching collection of artifacts and reproductions, we brought printed objects into the classroom. 3-D printing could be used at 
institutions that do not have direct access to collections or which have fragile or sensitive collections, or where enrollments are too high to mitigate risks. With concern for visual accessibility in mind, we designed a visual/tactile sensory lab with anthropology museum staff. (Supplemental Text 3). Additional learning goals were to examine how heritage and artifacts are made accessible to particular audiences and to critique how anthropology and art museums foster an exoticizing gaze of the "other" (Hodge 2018). In the lab, objects were placed on tables and covered with cloth. Students interacted with the objects either with their eyes closed, feeling underneath the cloths, or only experienced the object visually. Students then switched roles and interacted with a different set of objects. Relying on touch without sight challenged biases of aesthetic connections to cultural material and raised questions of producers' intent. Variations of this activity could be conducted with household and/or classroom items. The goal is to challenge people's preconceptions of objects and their use and to experience multiple ways of interacting with the material record.

Other assignments focused on addressing exclusionary or limited ways of representing the past (Supplemental Text 4). Students applied theoretical and methodological concepts from Whitney Battle-Baptiste's (2011) Black Feminist Archaeology to virtual representation of Andrew Jackson's Hermitage. They reviewed the Hermitage website to identify how past people were represented. Students then explored the Digital Archaeological Archive of Comparative Slavery (DAACS) resources from the Hermitage (specifically the Triplex to see materials recovered from within the living quarters of the enslaved). Students analyzed whose past was represented and for whom and whether the Hermitage pages muted the experiences of enslaved peoples. They were prompted to discuss lived versus imagined pasts, who has the right to excavate a plantation, and whether the Hermitage should serve as a tourist destination, much less a special events venue (Mullins 2017). Subsequently, students chose an artifact from DAACS and re-wrote a section of the Hermitage website to include the artifact and to center the experiences of the enslaved truthfully.

Another assignment analyzed how multiple stakeholders experience the sacred burial and effigy mounds on the Beloit College campus. Currently, faculty and students work inside and outside of the classroom to acknowledge Indigenous land and heritage, and the resulting institutional harm that comes with building a college atop a mound group. In this course, we have students explore campus and the surrounding areas to identify and assess the conditions of the Beloit College Mound Group. Students thus learn about Native earthworks and related responsibilities for non-descendant stewards on Native lands. When possible, HoChunk tribal members participate in conversation with the students about their lived experiences today; these conversations underscore the experiences of Native communities, and why their priorities and concerns often do not align with those of non-Native archaeologists.

A final project--the "anti-colonial archaeology textbook--bound archaeological knowledge-making to current social concerns and was made accessible by offering a menu of modalities in which students convey their knowledge: writing prose, infographics, animations, podcasts, or other media. Students collaborated in teams to create multimedia chapters for the 
textbook they would want to read in an introductory archaeology course following our pedagogical principles (Supplemental Text 5).

\section{Outcomes of Revising the Introductory Archaeology Course}

\section{Students Reflect on Outcomes}

To assess the outcomes of these changes to our course, Quave assigned reflective essays, following Hutchings and La Salle (2014:49). Students answered the same questions about archaeology at the beginning and end of the semester to assess if/how their understanding of archaeology's relevance changed. With IRB approval, Quave obtained informed consent from 16 of 24 students from a Fall 2017 section for textual analysis of their pre-course and post-course essays. We focus our analysis on two of the questions (Supplemental Text 6):

- Who does archaeology benefit and who does it harm?

- How, if at all, do you see your interests reflected in the practice and profession of archaeology?

Students wrote their pre-course assessments after we had discussed the problems of terms such as "New World" and "prehistory", which likely impacted some views. However, we believe these assessments reveal how students moved from a superficial understanding of archaeology being both beneficial and harmful to living people (as 13/16 students stated in the pre-term assessment $)^{2}$ to a post-term understanding of the complex ways that archaeology is beneficial and harmful to different kinds of stakeholders in various situations. We are not suggesting students were ignorant of the field at the start of term; in fact, many were anthropology majors who already had a passing understanding of the field. For example, one student wrote, "By studying artifacts and other physical remains it can give clues not only to the past but to our present and our future." Rather, we hypothesized that they would--by semester's end--be able to articulate the challenges and possibilities of the field more confidently and with greater nuance and that they would orient toward solutions.

In the pre-term assessment, the majority of students stated archaeology could be both harmful and beneficial and there were some patterns in how they described the impacts. Several mentioned the harmful effects on Indigenous peoples, especially when sacred objects are decontextualized in museums and when researchers enter into (formerly) colonized places to conduct fieldwork without community collaboration. A few students started the semester with a bleak outlook on archaeology; for example: "In the past, archaeology has always benefited white men, the conquerors and imperialists, and was unfair to the native populations of many areas of the world. Archaeology is similar to other branches of anthropology which have been used to form hierarchies and help with the colonization and manipulation of certain groups." Another theme from the pre-term assessment was a nostalgia of associating archaeology with childhood memories of visiting ancient sites and museums or seeing artifacts on family farms. Even among 
students who critiqued the colonial roots of the field, there were nostalgic responses to the prompts (with emphasis on visiting monumental sites or collecting).

In the post-term assessments, we did find shifts in students' understanding. They explained the effects of archaeology on different stakeholders with greater nuance. They described the impossibility of archaeology being done without bias and focused on the unintended impacts on descendant communities' wellbeing, especially related to human remains and sacred objects. Many responded that some archaeologists are aware of the ways the discipline is harmful and are working to mitigate the negative impacts on stakeholders (12/16).

While some students began the semester indicating that they saw archaeology as irredeemably harmful, by the end of the semester, those same students articulated ways of lessening harmful impacts. They wrote that some descendant and stakeholder communities that are socially marginalized can reap benefits from archaeological research when it is undertaken in ways that de-center normative viewpoints or promote self-determination (9/16). They had not written in those ways in the pre-term assessments. One post-term assessment included: "If we try to look through the past with different theoretical lenses that are not centering our own privilege and our own culture we may come up with different answers. We can use archaeology to make space for those who are not given space currently." In contrast, the one student who explicitly stated in the pre-term assessment that they did not see archaeology as harmful offered several examples in the post-term assessment about the potential for harm.

The overall takeaway from the student responses was that the course impacted their understanding in productive ways. In describing how archaeology specifically benefits people, students were able to articulate lessons from the past for climate change responses, sustainability, and identity and wellbeing. Two quotes from the post-term assessments highlight how the course helped students question what they thought they already knew and to value the revisions we made:

Example 1: "As someone who cares deeply about social-justice and the inequities that I see and experience [..] I see it as my job to use archaeology as a tool to reorient my understanding of the world. Much of what I was taught as fact throughout my schooling is nothing more than interpretation, full of biases and inaccuracies. This course has given me the tools to take nothing I learn for granted, to humble and silence my voice in respect of those around me, and how to take pride in confronting my own preconceived notions and biases, both conscious and not." Example 2: "I feel like what I've done in this class is more important than knowing the exact timeline of human existence."

Pursuant to the revisions made to the course, the archaeology introduction survey became an elective for students majoring in the college's Critical Identity Studies program (CRIS). The CRIS program is interdisciplinary, intersectional, social justice-oriented, and investigates "how gender, race, ethnicity, socio-economic class, sexuality, dis/ ability, nation, non/religiosity, and region shape identities" (Beloit College 2019b). The inclusion of the archaeology course into the CRIS curriculum is a recognition that learning about the past is a way to understand and improve society's present and future. 
Continued research on student reflections should include reporting on demographics in order to cross-reference student responses to the course with their social identities. At this point, we can report on some aspects of the enrollment trends that resulted from the course revision.

\section{Quantifiable Outcomes in Enrollment}

Adoption of the new curriculum shifted the racial demographics of who enrolled in the introductory course (Supplemental Table 3), but also in the elective follow-up Principles of Archaeology course (Supplemental Table 4). While there are many social identities systemically excluded from archaeology, these enrollment data allow us to quantify transitions in race and ethnicity for now. ${ }^{3}$ The new curriculum was adopted in Fall 2017 and taught under the previous title and course description, meaning that students who enrolled in the Fall 2017 course expected to encounter the traditional content and structure. The new course title and description appeared in time for Spring 2018 registration. Beginning in Spring and Fall 2019, students could enroll in a cross-listed section in Critical Identity Studies (CRIS) as an elective for that major. The enrollment data suggest that the new content and approach, bolstered by inclusion within the CRIS curriculum, disrupted the previous demographic makeup of the course. In 2018, following the course revision, we saw an increase in the proportion of students of color (all race and ethnic identities other than white, non-Hispanic) above that found prior to the revision (Figure 2).

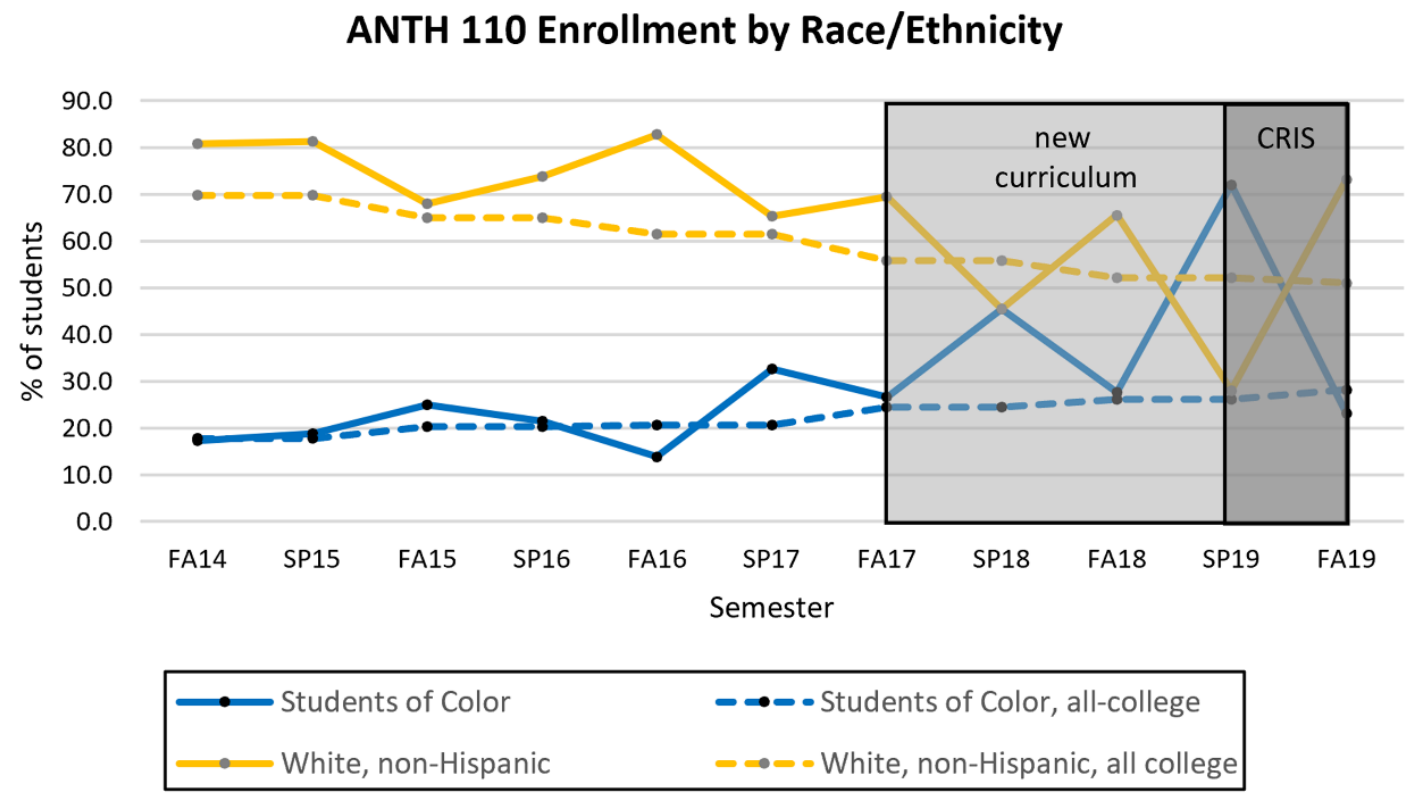


Figure 2. Enrollment trends for ANTH 110 by race and ethnicity (simplified as white, nonHispanic versus students of color) from Fall 2014 to Fall 2019 (course $\mathrm{N}=362$ ). The light grey area is when the revised course was introduced and dark gray is when the course was cross-listed with Critical Identity Studies. (note that underlying data are found in the supplemental materials on $A A P$ website for this article)

However, the trajectory differs in Spring versus Fall semesters for the last two years. We attribute this to the current catalog description which does not adequately capture the anticolonial approach taken since Fall 2017. It reads:

Archaeology: Lessons from the Past. All human societies face challenges, including those relating to power, identity, conflict, health, sustainability, and climate change. Using scientific and humanistic methods and theories, archaeology provides unique lessons for addressing such issues in the present and the future. In this course, we begin with an introduction to basic archaeological methods and theories, as well as the major trends of prehistory. Throughout the remainder of the class, we analyze case studies to better understand how societies succeed or fail when faced with specific challenges within different social, political, and environmental contexts. (Beloit College 2019a) Students are more likely to hear about the course's anti-colonial position through word-of-mouth on a SLAC campus. Because so many first-year students enroll based only on the catalog description, the enrollment demographics appear different in the Fall versus the Spring, when more students of color tend to enroll.

The impact of the course revision is more apparent down the line in the mid-level methods course, Principles of Archaeology. This course involves active learning, including small-scale excavations on campus and class projects directed at preserving and educating the community about the importance of the campus mounds. However, enrollment by students of color historically sat well below the college average. This trend shifted, however, in Fall 2019. Most of the students in the Fall 2019 ANTH 216 class were introduced to archaeology through the new ANTH 110 curriculum and, at 46.7 percent, the Principles course enrolled students of color well above the college average of 28.2 percent (Figure 3). Principles of Archaeology is not a required course in the general college curriculum nor the major/minor, so students choosing to continue to the intermediate level in the subdiscipline is notable (it's not just that the pipeline demographics shifted at the college, but also that students of color chose to continue learning in the archaeology subfield). We will continue to assess these enrollment trajectories and hope to collaborate with other campuses to implement these reforms for a more inclusive and representative archaeology. 


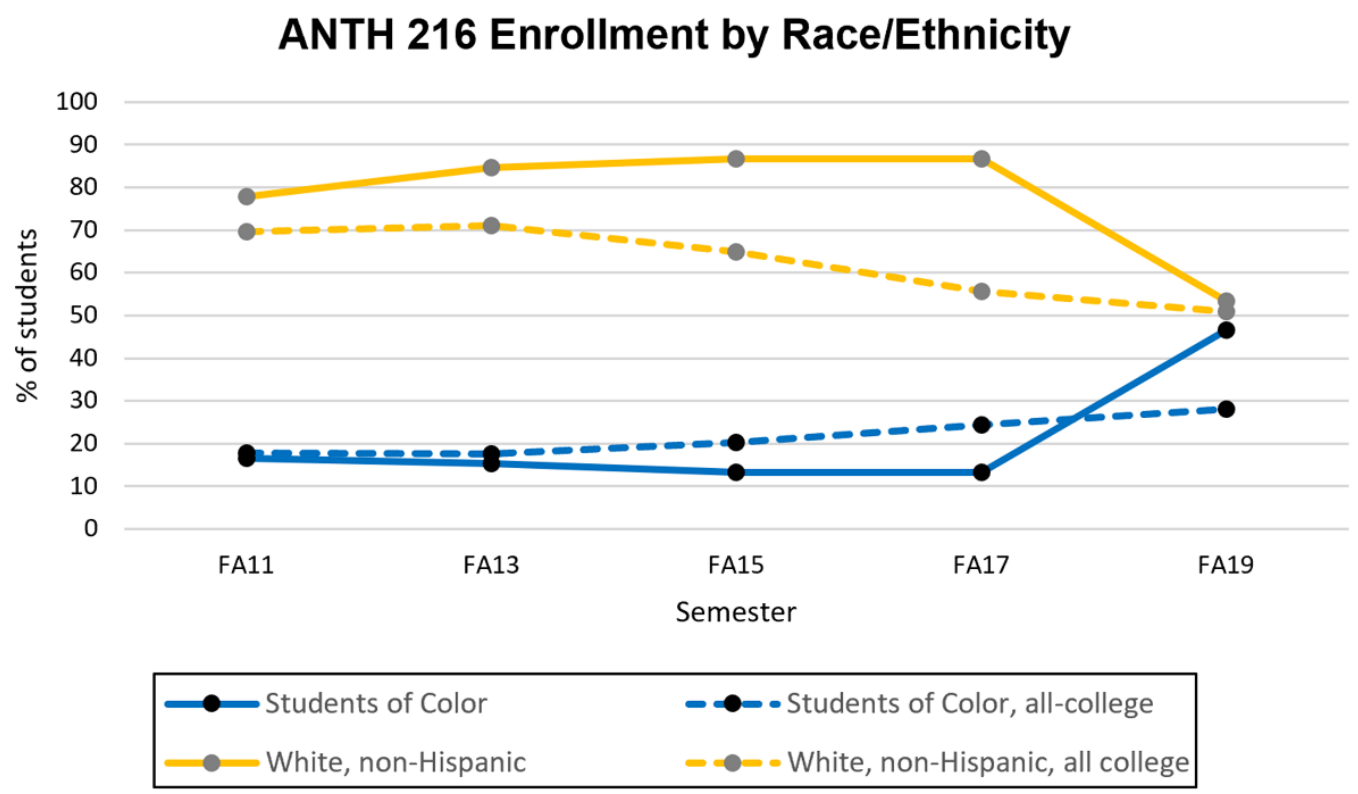

Figure 3. Enrollment trends for ANTH 216, the mid-level methods course in archaeology, by race and ethnicity from Fall 2011 to Fall $2019(\mathrm{~N}=76)$. Fall 2019 was the first time students enrolled after the revision of the introductory course.

\section{Conclusions}

In this study of the processes and impacts of revising our introductory archaeology course we demonstrate that there is an urgent need to reimagine how we teach postsecondary archaeology. This urgency is due to the exclusionary and marginalizing character of much archaeological work and archaeological knowledge production, both historically and presently. The campus on which this course was developed is the ancestral territory of Indigenous peoples, made visible by the presence of 20 conical, linear, and animal effigy mounds that sit between academic buildings. As settlers on this Indigenous land, and in a country built by enslaved Africans, we have a responsibility to actively address past and present structural violence.

In teaching archaeology and thus producing archaeological knowledge, we advocate for re-centering the archaeological curriculum by rejecting traditional textbook-guided ways of presenting the study of the past. We show how harnessing the methods, theories, and case studies already in the academic and non-academic literature can generate a classroom that better meets the needs of all learners. Furthermore, we find that this way of teaching archaeology facilitates greater diversity and increases diversity in ways of knowing, and thus could lead to greater equity and justice within the profession. Revising the introductory archaeology course is one of many changes that must be made in the discipline. 
The values that guided our work here are not novel; we build on the aspirations others share for an "effective archaeology" (Stahl 2020). While we did not use the Society for American Archaeology's Principles for Curricular Reform (Bender 2000) in our course design, we find that we are closely aligned with them. Drafted at the turn of this century, they emphasize archaeology as a nonrenewable resource to be stewarded in consultation with "various publics" (Bender 2000:32) and urge archaeologists not to claim sole ownership over the past. They emphasize the role that archaeology plays in helping "students think productively about the present and future,” engaging “diverse audiences” (Bender 2000:32-33).

As society changes and we as instructors come to new realizations of the barriers to and possibilities for equity and justice, we continue to revise our approach by asking who is helped and who is harmed by archaeological knowledge production? To teach archaeology is to produce the discipline and we find that this comprehensive revision of our curriculum more closely adheres to the discipline we aspire to work for and within. What makes us interested in archaeology is the endeavor to reconstruct the processes of the past in service of a better future and to do so in a way that centers the needs and priorities of diverse stakeholders. Those values should be incorporated into teaching the discipline from the very first day students encounter it.

Acknowledgments. The study of student writing responses was undertaken with permission from the Institutional Review Board of Beloit College and we thank them for their timely review. Quave's efforts in course revision were funded through a grant from the Andrew Mellon Foundation to Beloit College ("Decolonizing Pedagogies") while she was faculty there and she is grateful to Lisa Anderson-Levy for consultations on the course. Greiff and Agnew thank Dr. Sonya Maria Johnson for teaching us to prioritize inclusive nomenclature and be empathetic learners and educators. We thank Ellenor Anderbyrne for providing enrollment data, the Logan Museum staff (Nicolette Meister, Dan Bartlett, and Bill Green) for assistance with museum collections, and Jedidiah Rex for UDL consultation. With Fie and Agnew, the following students collaborated in Spring 2017 to identify case studies: Christopher Allen, Alex Flores, Faith Macdonald, Sarah Record, and Heather Warner. Sarah Kennedy and Scotti Norman generously provided feedback in the draft stage. We thank the very helpful anonymous reviewers and Sarah Herr. Most of all, thank you to our BIPOC peers, collaborators, and community stakeholders who have influenced our thinking on these issues and thank you to the students of ANTH 110 who patiently allowed us the space to experiment and consented for us to share their thoughts about the impacts of the course changes.

\section{Notes}

1. Quave and Fie were each instructors-of-record for their own section of the course, while Greiff and Agnew were teaching assistants in one section each. Our various social identities and backgrounds are germane to how we approached the course and its revision. We recognize that instructors of marginalized identities may be confronted with higher levels of 
student resistance when teaching in the ways recommended here, as literature on student perceptions and evaluations demonstrates (Aruguete et al. 2017; Smith et al. 2017).

Quave: I am a white, cisgender woman from a low-income, first-generation college student background. The risks I take on when teaching this way are few compared to my colleagues who are Black, Indigenous, and/or people of color (BIPOC), especially those from multiply marginalized identities (e.g., Shelton 2020).

Fie: I am a cisgender, heterosexual, white woman from a middle-class, first-generation college student background. As a tenured faculty member in a department recognized for its strong enrollments and forward-thinking pedagogies, I assume little risk in embracing an anti-colonial stance. I also benefit from the hard work of my colleagues of color who have shouldered much of the work of decolonizing the department and the college.

Greiff: I am a cisgender, asexual adopted Chinese American from a low-income family, raised in a rural, predominantly white town. I often use my identity and experiences to help inform my teachings. I use these aspects to help cultivate a palpable example to people of privilege and empathize with people from other marginalized groups.

Agnew: I am a cisgender, bisexual white woman from a middle income, privately educated, conservative church family. I aim to use my privilege and energy to help others and myself (un)learn in a constructive and sustainable manner.

2. 2/16 students stated pre-term that archaeology benefits nearly everyone. 1/16 did not submit a pre-term assessment.

3. We chose not to describe gender or race-gender patterns here due to the fact that each year's enrollments are too small to meaningfully identify patterns cross-tabulating more than one variable. We also chose to maintain a simplified dichotomy of white students and students of color in order to avoid revealing identifying information about students. "People of color" is a reductive category (Vidal-Ortiz 2008) and we intend for future research to include specific racial and ethnic categories once sufficient time has passed to be able to collapse multiple post-revision semesters for comparison to the pre-revision enrollment trends.

\section{Supplemental Materials}

For supplementary material accompanying this paper, visit [link].

Supplemental Text 1. Syllabus from the first semester in which the course was revised, with an additional column in the schedule that includes notes for lesson planning.

Supplemental Text 2. Excavation report/reflection assignment instructions.

Supplemental Text 3. Instructions for in-class activity on sensory experiences with artifacts, comparison of art/artifact dichotomies, and critique of the anthropological gaze.

Supplemental Text 4. Instructions for in-class activity on interpreting histories of enslaved peoples. 
Supplemental Text 5. Assignment instructions and evaluation criteria for the Anti-Colonial Archaeology Textbook.

Supplemental Text 6. Pre-term and post-term assessment instructions. Responses were used to investigate the impacts of the course revisions.

Supplemental Table 1. Comparison of Tables of Contents of Major Introductory Archaeology Textbooks That Are Organized by Complexity.

Supplemental Table 2. Comparison of Tables of Contents of Major Introductory Archaeology Textbooks That Are Organized by Geographic Regions.

Supplemental Table 3. Historic Enrollment Data for Introductory Archaeology Survey Course.

Supplemental Table 4. Historic Enrollment Data for Intermediate-level Archaeological Methods Course.

\section{Data Availability Statement}

Sample course materials, including syllabuses and assignments are available in the Supplemental Materials. The student reflection papers are not available for sharing due to consent agreements that the papers remain password-protected. Simplified college enrollment data discussed here is included in the Supplemental Materials. The authors chose to include the dichotomized race/ethnicity variable rather than full details of race and ethnicity in order to avoid making students identifiable. For that same reason, gender and other social identity variables are excluded.

\section{References Cited}

Abu Hadal, Katherine

2013 Why Native American Art Doesn't Belong in the American Museum of Natural History. Indian Country Today, February 20, 2013. https://indiancountrytoday.com/archive/whynative-american-art-doesn-t-belong-in-the-american-museum-of-natural-historyXwtSiOVz_EGnN81GEEZ-mQ, accessed June 23, 2020.

Agbe-Davies, Anna S.

2002 Black Scholars, Black Pasts. SAA Archaeological Record 2(4):24-28. 
Arnold, Bettina

1990 The Past as Propaganda: Totalitarian Archaeology in Nazi Germany. Antiquity 64(244):464-478. DOI: 10.1017/S0003598X00078376.

Aruguete, Mara S., Joshua Slater, and Sekela R. Mwaikinda

2017 The Effects of Professors' Race and Clothing Style on Student Evaluations. The Journal of Negro Education 86(4):494-502. DOI: 10.7709/jnegroeducation.86.4.0494.

Atalay, Sonya

2006 Indigenous Archaeology as Decolonizing Practice. American Indian Quarterly 30(3/4):280-310.

2008 Multivocality and Indigenous Archaeologies. In Evaluating Multiple Narratives: Beyond Nationalist, Colonialist, Imperialist Archaeologies, edited by Junko Habu, Clare Fawcett, and John M. Matsunaga, pp. 29-44. Springer, New York, New York.

Bahn, Paul

2012 Archaeology: A Very Short Introduction. 2nd ed.. Oxford University Press, New York.

Bardolph, Dana N.

2014 A Critical Evaluation of Recent Gendered Publishing Trends in American Archaeology. American Antiquity 79(3):522-540. DOI:10.2307/43184920.

Battle-Baptiste, Whitney

2007 "In This Here Place": Interpreting Enslaved Homeplaces. In Archaeology of Atlantic Africa and the African diaspora, edited by Akinwumi Ogundiran and Toyin Falola, pp. 233-248. Indiana University Press, Bloomington.

2011 Black Feminist Archaeology. Routledge, New York.

Beloit College

2019 Critical Identity Studies. Beloit College.

https://www.beloit.edu/academics/critical-identity-studies/, accessed November 13, 2019.

Bender, Susan J.

2000 A Proposal to Guide Curricular Reform for the Twenty-First Century. In Teaching Archaeology in the Twenty-First Century, edited by Susan J. Bender and George S. Smith, pp. 29-48. Society for American Archaeology, Washington, D.C. 


\section{Black Trowel Collective}

2016 Foundations of an Anarchist Archaeology: A Community Manifesto. Savage Minds, October 31, 2016. https://savageminds.org/2016/10/31/foundations-of-an-anarchistarchaeology-a-community-manifesto/, accessed June 23, 2020.

Bond, Sarah E.

2018 Pseudoarchaeology and the Racism behind Ancient Aliens. Hyperallergic, November 13, 2018. https://hyperallergic.com/470795/pseudoarchaeology-and-the-racismbehind-ancient-aliens/.

Boothe, Kathleen A., Marla J. Lohmann, Kimberly A. Donnell, and D. Dean Hall

2018 Applying the Principles of Universal Design for Learning (UDL) in the College Classroom. Journal of Special Education Apprenticeship 7(3):1-13.

Brown II, M. Christopher, and T. Elon Dancy II

2010 Predominantly White Institutions. In Encyclopedia of African American

Education, pp. 524-526. SAGE Publications, Inc., Thousand Oaks, California.

Carlson, Dennis, and Michael W. Apple

2018 Introduction: Critical Educational Theory in Unsettling Times. In

Power/Knowledge/Pedagogy: The Meaning of Democratic Education in Unsettling Times, edited by Dennis Carlson and Michael W. Apple, pp. 1-38. Routledge, New York.

Carter, Chelsey R.

2018 Racist Monuments Are Killing Us. Museum Anthropology 41(2):139-141.

DOI: $10.1111 /$ muan.12182.

CAST

2018a UDL: Frequently Asked Questions. CAST.

http://udlguidelines.cast.org/more/frequently-asked-questions, accessed July 1, 2020.

2018b Universal Design for Learning Guidelines version 2.2. CAST.

http://udlguidelines.cast.org/, accessed July 3, 2020.

Chazan, Michael

2017 World Prehistory and Archaeology: Pathways through Time. 4th ed. Routledge, New York.

Cobb, Charles R. 
2014 The Once and Future Archaeology. American Antiquity 79(4):589-595.

DOI: $10.7183 / 0002-7316.79 .4 .589$.

Conkey, Margaret W.

2007 Questioning Theory: Is There a Gender of Theory in Archaeology? Journal of Archaeological Method and Theory 14(3):285-310. DOI:10.1007/s10816-007-9039-z.

Dei, George J. Sefa, and Alireza Asgharzadeh

2001 The Power of Social Theory: The Anti-Colonial Discursive Framework. The

Journal of Educational Thought (JET) / Revue de la Pensée Éducative 35(3):297-323.

Deloria, Vine

1997 Red Earth, White Lies. Fulcrum Publications, Golden, Colorado.

Denial, Catherine

2019 A Pedagogy of Kindness. Hybrid Pedagogy, August 15, 2019.https://hybridpedagogy.org/pedagogy-of-kindness/, accessed August 20, 2019.

Dunn, Stacy

2016 Witches, Shamans, and Looters: Alternative Uses and Contemporary Ritual Reuse of Archaeological Remains in the North-Central Coast of Peru. In Lost City, Found Pyramid: Understanding Alternative Archaeologies and Pseudoscientific Practices, edited by Jeb J. Card and David S. Anderson, pp. 46-67. University of Alabama Press, Tuscaloosa.

Edmonds, Brittney

2019 The Professional is Political: On Citational Practice and the Persistent Problem of Academic Plunder. Journal of Feminist Scholarship 16(Fall):74-77.

DOI: $10.23860 /$ jfs.2019.16.08.

Feder, Kenneth L.

2017 Frauds, Myths, and Mysteries: Science and Pseudoscience in Archaeology. 9th ed. Oxford University Press, New York.

FitzPatrick Sifford, Elena, and Ananda Cohen-Aponte

2019 A Call to Action. Art Journal 78(4):118-122.

Franklin, Maria

1997 Why Are There So Few Black American Archaeologists? Antiquity 71(274):799801. DOI:10.1017/S0003598X00085732. 
2005 Historical Archaeology That Matters Beyond Academics. In Unlocking the Past: Celebrating Historical Archaeology in North America, pp. 189-194. University Press of Florida, Gainesville.

Franklin, Maria, and Nedra Lee

2020 African American Descendants, Community Outreach, and the Ransom and Sarah Williams Farmstead Project. Journal of Community Archaeology and Heritage 7(2):135-148. DOI: org/10.1080/20518196.2020.1718408.

Franklin, Maria, and Robert Paynter 2010 Inequality and Archaeology. In Voices in American Archaeology, edited by Wendy Ashmore, Dorothy Lippert, and Barbara J. Mills, pp. 94-130. Society for American Archaeology, Washington, D.C.

Freeman, Scott, Sarah L. Eddy, Miles McDonough, Michelle K. Smith, Nnadozie Okoroafor, Hannah Jordt, and Mary Pat Wenderoth

2014 Active Learning Increases Student Performance in Science, Engineering, and Mathematics. Proceedings of the National Academy of Sciences 111(23):8410-8415. DOI: org/10.1073/pnas.1319030111.

Freire, Paulo 1985 Pedagogy of the Oppressed. Penguin.

Fulkerson, Tiffany J., and Shannon Tushingham

2019 Who Dominates the Discourses of the Past? Gender, Occupational Affiliation, and Multivocality in North American Archaeology Publishing. American Antiquity 84(3):379-399. DOI:10.1017/aaq.2019.35.

Gnecco, Cristóbal 1999 Multivocalidad Histórica: Hacia una cartografía postcolonial de la arqueología. Departamento de Antropología, Universidad de los Andes, Bogotá, Colombia.

Grayson, Donald K., and David J. Meltzer

2003 A Requiem for North American Overkill. Journal of Archaeological Science 30:585-593. DOI:10.1016/S0305-4403(02)00205-4.

Hamilakis, Yannis 2004 Archaeology and the Politics of Pedagogy. World Archaeology 36(2):287-309. DOI: $10.1080 / 0043824042000261031$. 
Haraway, Donna

1988 Situated Knowledges: The Science Question in Feminism and the Privilege of

Partial Perspective. Feminist Studies 14(3):575-599. DOI:10.2307/3178066.

Harbin, M. Brielle, Amie Thurber, and Joe Bandy

2019 Teaching Race, Racism, and Racial Justice: Pedagogical Principles and

Classroom Strategies for Course Instructors. Race and Pedagogy Journal 4(1):1-37.

Hart, Siobhan M., and Elizabeth S. Chilton

2015 Digging and Destruction: Artifact Collecting as Meaningful Social Practice.

International Journal of Heritage Studies 21(4):318-335. DOI: 10.1080/13527258.2014.934267.

Heath-Stout, Laura E.

2019 Diversity, Identity, and Oppression in the Production of Archaeological Knowledge. Ph.D. dissertation, Boston University, Boston,Massachusetts.

2020 Who Writes about Archaeology? An Intersectional Study of Authorship in Archaeological Journals. American Antiquity 85(3):407-426.. DOI:10.1017/aaq.2020.28.

Heath-Stout, Laura E., and Elizabeth M. Hannigan

2020 Affording Archaeology: How Field School Costs Promote Exclusivity. Advances in Archaeological Practice 8(2):123-133. DOI:10.1017/aap.2020.7.

Hodge, Christina J.

2018 Decolonizing Collections-Based Learning: Experiential Observation as an Interdisciplinary Framework for Object Study. Museum Anthropology 41(2):142-158. DOI: $10.1111 /$ muan.12180.

hooks, bell

1994 Teaching to Transgress: Education as the Practice of Freedom. Routledge, New York.

Hugo, Kristin

2017 3-D Printing Allows Blind People to "See" Civil War Artifacts at Virginia Museum. Newsweek, October 19, 2017. https://www.newsweek.com/3d-printing-blind-can-seemuseum-artifacts-688008, accessed June 24, 2020.

Hutchings, Rich, and Marina La Salle

2014 Teaching Anti-Colonial Archaeology. Archaeologies: Journal of the World Archaeological Congress 10(1):27-69. DOI:10.1007/s11759-014-9250-y. 
Kishimoto, Kyoko

2018 Anti-Racist Pedagogy: From Faculty's Self-Reflection to Organizing within and beyond the Classroom. Race Ethnicity and Education 21(4):540-554.

DOI: $10.1080 / 13613324.2016 .1248824$.

Lane, Paul J.

2015 Archaeology in the Age of the Anthropocene: A Critical Assessment of Its Scope and Societal Contributions. Journal of Field Archaeology 40(5):485-498.

DOI:10.1179/2042458215Y.0000000022.

Logan, Amanda L.

2016 "Why Can't People Feed Themselves?": Archaeology as Alternative Archive of

Food Security in Banda, Ghana. American Anthropologist 118(3):508-524.

http://anthrosource.onlinelibrary.wiley.com/doi/abs/10.1111/aman.12603, accessed July 31, 2019.

Lyman, R. Lee

2010 American Archaeology Textbooks as Reflections of the History of the Discipline.

North American Archaeologist 31(1):1-25. DOI: doi:10.2190/NA.31.1.a.

Mahuika, Rangimarie

2008 Kaupapa Maori Theory Is Critical and Anti-Colonial. MAI Review 3:17.

McGuire, Randall H.

2008 Archaeology as Political Action. University of California Press, Berkeley.

Merriman, Nick (editor)

2004 Public Archaeology. Routledge, London.

Montenegro, Erick, and Natasha A Jankowski

2017 Equity and Assessment: Moving Towards Culturally Responsive Assessment.

Occasional Paper \#29. National Institute for Learning Outcomes Assessment (NILOA), University of Illinois, Urbana and Indiana University, Bloomington.

https://learningoutcomesassessment.org/documents/OccasionalPaper29.pdf, accessed October $15,2019$.

Morgan, Colleen

2019 Reloading the Archaeological Canon: Decolonising the Undergraduate Archaeology Curriculum. 
Quave et al. "Centering the margins" (preprint)

https://middlesavagery.files.wordpress.com/2019/04/pgcap_research_project_morgan_without_a ppendices.pdf. Accessed June 24, 2020.

Mott, Carrie, and Daniel Cockayne

2017 Citation Matters: Mobilizing the Politics of Citation toward a Practice of 'Conscientious Engagement.' Gender, Place \& Culture 24(7):954-973.

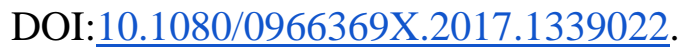

Mullins, Paul R.

2017 The Aesthetics of Bliss and Trauma in Plantation Weddings. Archaeology and Material Culture, April 30, 2017. https://paulmullins.wordpress.com/2017/04/30/the-aestheticsof-bliss-and-trauma-in-plantation-weddings/, accessed June 24, 2020.

O’Brien, Judith Grunert, Barbara J. Millis, and Margaret W. Cohen 2009 The Course Syllabus: A Learning-Centered Approach. 2nd ed. John Wiley \& Sons.

Odewale, Alicia, Justin Dunnavant, Ayana Flewellen, and Alexandra Jones

2018 Archaeology for the Next Generation. Anthropology News 59(1):e210-e215.

DOI: $10.1111 /$ AN.729.

Oland, Maxine $\mathrm{H}$.

2020 Teaching Archaeology with Inclusive Pedagogy. Journal of Archaeology and Education 4(1):1.

Olson, David R.

1980 On the Language and Authority of Textbooks. Journal of Communication 30(1):186-196. DOI:10.1111/j.1460-2466.1980.tb01786.x.

Perry, Sara

2019 The Enchantment of the Archaeological Record. European Journal of Archaeology 22(03):354-371. DOI:10.1017/eaa.2019.24.

Richardson, Lorna-Jane, and Jaime Almansa-Sánchez

2015 Do You Even Know What Public Archaeology Is? Trends, Theory, Practice, Ethics. World Archaeology 47(2):194-211. DOI:10.1080/00438243.2015.1017599.

Sandweiss, Daniel H., and Alice R. Kelley 
2012 Archaeological Contributions to Climate Change Research: The Archaeological Record as a Paleoclimatic and Paleoenvironmental Archive. Annual Review of Anthropology 41(1):371-391. DOI:10.1146/annurev-anthro-092611-145941.

SBA

About. The Society of Black Archaeologists.

https://www.societyofblackarchaeologists.com/about, accessed July 2, 2020.

2020 "Archaeology in the Time of Black Lives Matter" Twitter, June 25, 2020, 2:58

p.m., https://twitter.com/SbaArch/status/1276246837993889795?s=20, accessed July 2, 2020.

Shelton, Cecilia

2020 Shifting Out of Neutral: Centering Difference, Bias, and Social Justice in a Business Writing Course. Technical Communication Quarterly 29(1):18-32.

DOI: $10.1080 / 10572252.2019 .1640287$.

Smith, Laura, Susan Kashubeck-West, Gregory Payton, and Eve Adams

2017 White Professors Teaching about Racism: Challenges and Rewards. The

Counseling Psychologist 45(5):651-668. DOI:10.1177/0011000017717705.

Southwell-Wright, William

2013 Past Perspectives: What Can Archaeology Offer Disability Studies? In Emerging

Perspectives on Disability Studies, edited by Matthew Wappett and Katrina Arndt, pp. 67-95.

Palgrave Macmillan.

Stahl, Ann Brower

2020 Assembling "Effective Archaeologies" toward Equitable Futures. American Anthropologist 122(1):37-50. DOI:10.1111/aman.13365.

Starck, Emily, and William Green

2014 Shattered Saucers, Broken Bottles, and Family Identity: Historical Archaeology on the Beloit College Campus. The Wisconsin Archeologist 95(1):110-112.

Stump, D.

2019 Digging for Indigenous Knowledge: 'Reverse Engineering' and Stratigraphic Sequencing as a Potential Archaeological Contribution to Sustainability Assessments. In The Oxford Handbook of Historical Ecology and Applied Archaeology, edited by Christian Isendahl and Daryl Stump, pp. 137-155. Oxford University Press, Oxford.

Supernant, Kisha, Jane Eva Baxter, Natasha Lyons, and Sonya Atalay (editors) 
Quave et al. "Centering the margins" (preprint)

2020 Archaeologies of the Heart. Springer International Publishing.

Takacs, David

2003 How Does Your Positionality Bias Your Epistemology? Thought \& Action 19(1):27-38.

TallBear, Kim

2014 Standing with and Speaking as Faith: A Feminist-Indigenous Approach to Inquiry. Journal of Research Practice 10(2):N17-N17.

Thiaw, Ibrahima

2011 Digging on Contested Grounds: Archaeology and the Commemoration of Slavery on Gorée Island, Senegal. In New Perspectives in Global Public Archaeology, edited by Katsuyuki Okamura and Akira Matsuda, pp. 127-138. Springer, New York.

Thistle, Paul C.

2012 Archaeology Excavation Simulation: Correcting the Emphasis. Journal of Museum Education 37(2):65-76. DOI:10.1080/10598650.2012.11510732.

Tuck, Eve, and K Wayne Yang

2012 Decolonization Is Not a Metaphor. Decolonization: Indigeneity, Education \& Society 1:1-40.

Vidal-Ortiz, Salvador

2008 People of Color. In Encyclopedia of Race, Ethnicity, and Society, edited by Richard T. Schaefer, pp. 1037-1039. SAGE Publications, London.

Watkins, Joe

2010 Wake Up! Repatriation Is Not the Only Indigenous Issue in Archaeology! In Bridging the Divide. Indigenous Communities and Archaeology into the 21st Century, edited by Caroline Phillips and Harry Allen, pp. 49-60. Routledge, New York.

White, William, and Catherine Draycott 2020 Why the Whiteness of Archaeology Is a Problem. SAPIENS, July 7, 2020. https://www.sapiens.org/archaeology/archaeology-diversity/, accessed July 8, 2020. 